\title{
PEMBELAJARAN BERBASIS LABORATORIUM VIRTUAL MELALUI GOOGLE CLASSROOM PADA MATERI HUKUM OHM UNTUK MENINGKATKAN KEMAMPUAN BERPIKIR KRITIS
}

\section{Marini Amalia Ocvianti, Dwi Sulisworo}

\author{
Program Studi Magister Pendidikan Fisika \\ Universitas Ahmad Dahlan \\ Jalan Pramuka 42, Sidikan, Umbulharjo, Yogyakarta 55161 \\ mariniamaliaku@gmail.com, sulisworo@gmail.com
}

\begin{tabular}{l|c|c|c} 
Diterima 6 Maret 2021 & Direvisi 28 April 2021 & Disetujui 7 Mei 2021 & Dipublikasikan 17 Mei 2021 \\
\hline \multicolumn{4}{|c|}{ https://doi.org/10.33369/jkf.4.1.67-76 }
\end{tabular}

\begin{abstract}
ABSTRAK
Learning Management System (LMS) merupakan sebuah aplikasi online yang dapat membantu merencanakan dan mengimplementasikan pembelajaran. Google Classroom adalah bentuk LMS yang mudah digunakan oleh pendidik maupun poeserta didik dalam proses pembelajaran yang kreatif dan inovatif. Inovasi pembelajaran pada masa pandemi Covid-19 menggunakan Google Classroom diharapkan akan menumbuhkan kemampuan prendidik untuk berpikir kritis. Telah dilakukan penelitian penggunaan Google Classroom pada pembelajaran berbasis laboratorium virtual pada materi Hukum Ohm kepada peserta didik Kelas XII di SMA Muhammadiyah 1 Yogyakarta. Menggunakan model pembelajaran discovery learning dengan pendekatan saintifik, maka dirancang metode pembelajaran diskusi dan eksperimen melaui tatap maya dengan Gmeet dan penugasan kelompok. Setelah dilaksanakan pembelajaran tersebutpeserta didik diminta untuk mengisi angket. Hasil yang diperoleh dari angket tersebut menunjukkan bahwa sebagian besar peserta didik menyetujui proses pembelajaran, penggunaan media, manfaat media, dan kefleksibelan proses pembelajaran menggunakan Google Classroom.Dari hasil ini maka selanjutnya penggunaan Google Classroom dalam pembelajaran bisa dilaksanakan untuk menumbuhkan cara berpikir kritis dalam pembelajaran dikombinasikan dengan pembelajaran secara tatap muka yang dikenal dengan sebutan blended learning. Oleh karena itu, penyesuaian model pembelajaran perlu dilakukan untuk terlaksananya blended learning.
\end{abstract}

Kata Kunci: Berpikir Kritis, Google Classroom, Laboratorium Virtual, LMS.

\begin{abstract}
Learning Management System (LMS) is an online application that can help plan and emplement learning. Google Classroom is a form of LMS that is easy to use by educators and students in a creative and innovative learning process. Learning innovation during the Covid-19 pandemic using Google Classroom is expected to foster the ability of educators to think critically. Research on the use of Google Classroom in virtual laboratory-based learning on Ohm's Law has been carried out for $3^{\text {rd }}$ grade students at SMA Muhammadiyah 1 Yogyakarta. Using the discovery learning model with a scientific approach, a discussion and experiment learning method through virtual face to face with Gmeet and group assignment was designed. After the learning was carried out, students were asked to fill out a questionnaire. The results obtained from the questionnaire showed thad most of students agreed to the learning process, the use and benefits of the media, and the flexibility of the learning process. From this resuts, the use of Google Classroom in learning can be continue to be implemented to foster critical thinking in learning combined with offline learning kwown as blended learning. Therefore, adjustment to the learning model need to be made for the implementation of blended learning.
\end{abstract}

Keywords:Critical Thinking,Google Classroom, LMS, Virtual Laboratory.

\section{PENDAHULUAN}

Learning Management System atau yang biasa disingkat dengan LMS merupakan sebuah aplikasi perangkat lunak yang dapat membantu merencanakan dan mengimplementasikan sebuah proses pembelajaran. Dalam satu dekade terakhir, penggunaan LMS dalam dunia pendidikan 
sebagai penunjang pembelajaran meningkat pesat. Selain dikembangkan oleh berbagai pengembang web besar, dengan lisensi komersial maupun lisensi open source, LMS juga bisa dikembangkan dengan jangkauan kecil yang menyesuaikan dengan kebutuhan pengguna, seperti misalnya LMS yang dikembangkan oleh sekolah (1).

LMS yang digunakan menyesuaikan dengan kebutuhan pembelajaran setiap peserta didik untuk mencapai pembelajaran yang efektif. Dengan kata lain, pendidik bisa merancang proses pengajaran yang dibutuhkan pada LMS. Gaya belajar bisa mempengaruhi pembelajaran. LMS memberikan pilihan alternatif gaya belajar secara virtual, selain dari tatap muka. Dengan perpaduan pembelajaran tatap muka dan virtual melalui LMS ini bisa meningkatkan kualitas pembelajaran. Kemudahan pada menu yang ditawarkan pada LMS sangat membantu pendidik dalam memvisualisasikan materi pembelajaran menjadi lebih menarik dan bervariasi. Selain itu, dengan menggunakan LMS, peserta didik dapat saling berbagi informasi dan dapat mengakses bahan ajar setiap saat dan pendidik dapat melaksanakan evaluasi setiap saat yang dapat mengukur pemahaman konsep peserta didik (2).

Dalam sebuah LMS diperlukan beberapa komponen, yaitu infrasuktur atau peralatan, konten atau isi, dan sistem atau aplikasi. Infrastruktur atau peralatan ini berupa komputer, server, dan jaringannya, internet dan perlengkapan multimedia. Peralatan ini dijalankan oleh admin sebagai penanggung jawab yang bertugas melakukan konfigurasi, pemeliharaan, dan monitoring jaringan. Konten dan bahan ajar yang ada pada LMS bisa dalam bentuk Multimedia-based Content (konten berbentuk multimedia interaktif) atau Text-based Content (konten berbentuk teks seperti pada buku pelajaran biasa). Konten atau isi pada LMS dilakukan oleh pendidik, disesuaikan dengan kebutuhan peserta didik sebagai bahan ajar. Sistem atau aplikasiperangkat lunak berfungsi untuk yang memvirtualisasi proses belajar mengajar konvensional berupa manajemen kelas, pembuatan materi atau konten, forum diskusi, sistem penilaian, sistem ujian online dan menu yang berhubungan dengan manajemen proses belajar mengajar, yang dapat dijalankan oleh peserta didik kapanpun dan dimanapun.

Dalam masa pandemi Covid-19, penggunaan LMS secara masif banyak digunakan dalam pebelajaran secara daring. Dengan dibatasinya pembelajaran secara tatap muka, maka dikembangkanlah inovasi pembelajaran secara tatap maya, baik dengan video, chat, maupun online learning dengan memanfaatkan LMS. Dengan kemajuan ilmu pengetahuan dan teknologi, penggunaan alat-alat bantu mengajar di sekolah bisa disesuaikan dengan perkembangan teknologi informasi (3). Dalam proses pembelajaran daring atau tatap maya dilakukan dengan bantuan teknologi informasi, karena hal ini secara umum sekarang menjadi kebutuhan dan tuntutan di masa pandemi ini.

Meskipun ada keterbatasan waktu dalam pembelajaran di masa pandemi, pendidik diharuskan bisa tetap meningkatkan efektivitas dan efisiensi pembelajaran. Oleh karena itu, pendidik perlu menggunakan berbagai model pembelajaran yang kreatif dan inovatif, sehingga proses pembelajaran menjadi lebih menarik dan tidak membosankan. Dengan model pembelajaran ini diharapkan transfer ilmu pengetahuan, penanaman konsep materi, dan diskusi intensif mudah dilakukan dan diterima dengan baik oleh peserta didik (4). Oleh karena itu perlu dipersiapkan berbagai media pembelajaran dalam LMS karena akan menjadikan proses pembelajaran menjadi lebih bervariasi dan tidak membosankan.

E-learning yang mampu meningkatkan kemampuan kognitif peserta didik adalah e-learning yang mempunyai tingkat interaktifitas pengguna tinggi, yang selain menyajikan materi pembelajaran dalam bentuk file baik itu dalam format words, powerpoint, html atau PDF tapi $e$ learning tersebut juga mempunyai nilai lebih menu yang lebih bersifat interaktif, baik itu dalam bentuk evaluasi online yang lebih bervariasi, konsultasi online maupun fasilitas chatting (5). Laboratorium virtual dapat mendukung kegiatan praktikum di laboratorium yang bersifat interaktif, dinamis, animatif dan berlingkungan virtualsehingga tidak membosankan dan dapat mendukung keinginan pengguna untuk mempelajari dan memahami materi secara efektif serta memfasilitasi pendidikan karakter peserta didik (6). 
Salah satu LMS yang banyak digunakan adalah Google Classroom. Google Classroom merupakan LMS berbasis aplikasi yang dapat dimanfaatkan sebagai platform manajemen pembelajaran online (7). Aplikasi ini dilengkapi berbagai fitur yang dapat dimanfaatkan sebagai fasilitas pendukung proses pembelajaran. Aplikasi ini sering digunakan sebagai pendukung pada proses pembelajaran konvensional, blended, maupun online (8), (9),(10). Selain itu, Google Classroom merupakan salah satu aplikasi yang dapat digunakan sebagai LMS dan bersifat fleksibel, aplikasi ini dapat diimplementasikan pada materi saintik, sochum, dan materi-materi pembelajaran yang terkait dengan teknologi informasi dan komunikasi (8), (11). Aplikasi ini memiliki berbagai fitur dan fasilitas yang dapat dimanfaatkan untuk mendukung proses pembelajaran jarak jauh (7).

Dalam penelitian ini akan membahas permasalah mengenai keefektifan pembelajaran menggunakan Google Classroom pada masa pandemi Covid-19 yang disesuaikan dengan materi pelajaran yang bisa menumbuhkan cara berpikir kritis bagi peserta didik. Oleh karena itu disusunlah tujuan dari penelitian ini yaitu meningkatkan kemampuan berpikir kritis peserta didik dengan pembelajaran berbasis laboratorium virtual melalui Google Classroom pada materi Hukum Ohm.

\section{METODE PENELITIAN}

Proses inovasi pembelajaran dengan laboratorium virtual bisa dirancang melalui Google Classroom sebagai alternatif gaya belajar selain dari tatap muka. Dengan perpaduan inovasi pembelajaran tatap muka dan laboratorium virtual melalui Google Classroom bisa merangsang kemampuan berpikir kritis peserta didik. Kemudahan pada menu yang ditawarkan pada laboratorium virtual sangat membantu pendidik dalam memvisualisasikan eksperimen menjadi lebih menarik.

Dengan melakukan inovasi pembelajaran yang mengarah pada berpikir kritis, peserta didik bisa mengembangkan kemampuan berpikir dan kreatifitasnya sehingga pembelajaran menjadi lebih menyenangkan. Untuk melaksanakan inovasi pembelajaran yang meningkatkan kemampuan berpikir tingkat tinggi melalui laboratorium virtual pada Google Classroom, digunakan model pembelajaran discovery learning dengan metode saintifik, maka dibuat desain pembelajaran seperti tabel 1 .

Tabel 1. Desain Pembelajaran

\begin{tabular}{lllll}
\hline \multicolumn{1}{c}{ Materi } & \multicolumn{1}{c}{ Strategi } & Sumber Belajar & Interaksi Sosial & \multicolumn{1}{c}{ Penilaian } \\
\hline Listrik & Laboratorium & Modul dan PhET & Kerja sama tim & Portofolio berupa laporan \\
Dinamis: & Virtual & Colorado & dalam & hasil praktikum \\
Hukum & & & $\begin{array}{l}\text { pengambilan dan } \\
\text { pengolahan data }\end{array}$ & $\begin{array}{l}\text { menggunakan laboratorium } \\
\text { virtual }\end{array}$ \\
Ohm & & & \\
\hline
\end{tabular}

Dipilih salah satu materi yaitu Hukum Ohm yang merupakan materi ajar Fisika SMA kelas XII. Peserta didik diharapkan bisa membuktikan Hukum Ohm melalui eksperimen dengan laboratorium virtual yang dilaksanakan pada minggu ke-5 bulan Juli 2020 dengan sasaran peserta didik kelas XII SMA Muhammadiyah 1 Yogyakarta. Pembelajaran dan penugasan yang dikerjakan mengikuti diagram alir pada gambar 1 .

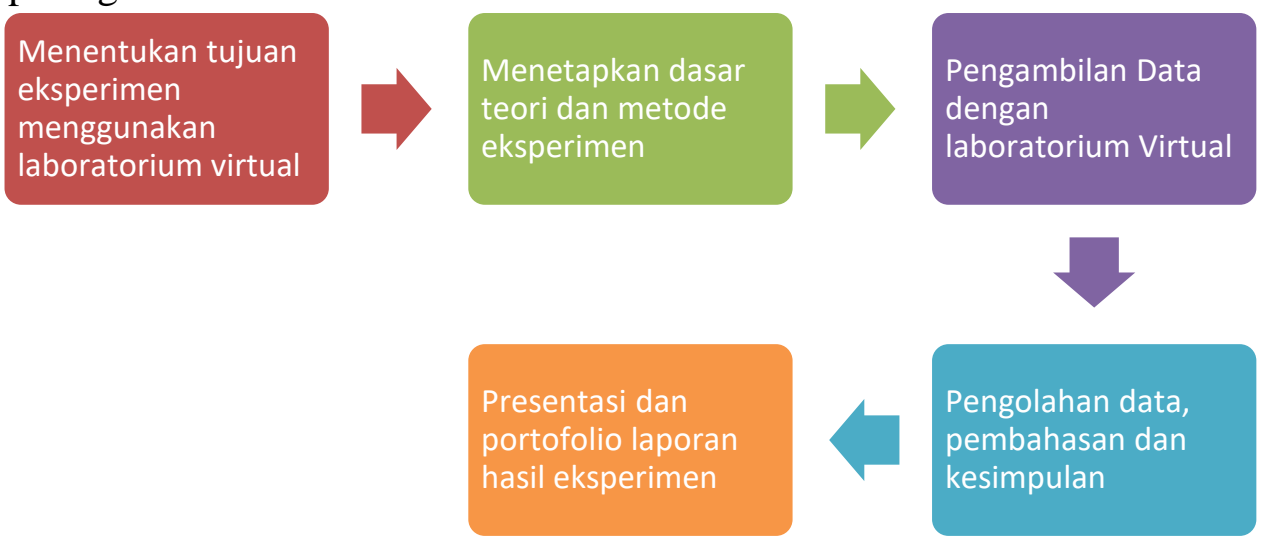

Gambar 1. Diagram Alir Pembelajaran Hukum Ohm 
Mind mapping untuk memetakan konsep-konsep pembelajaran yang meningkatkan kemampuan berpikir tingkat tinggi melalui laboratorium virtual pada Google Classroom disajikan pada gambar 2.

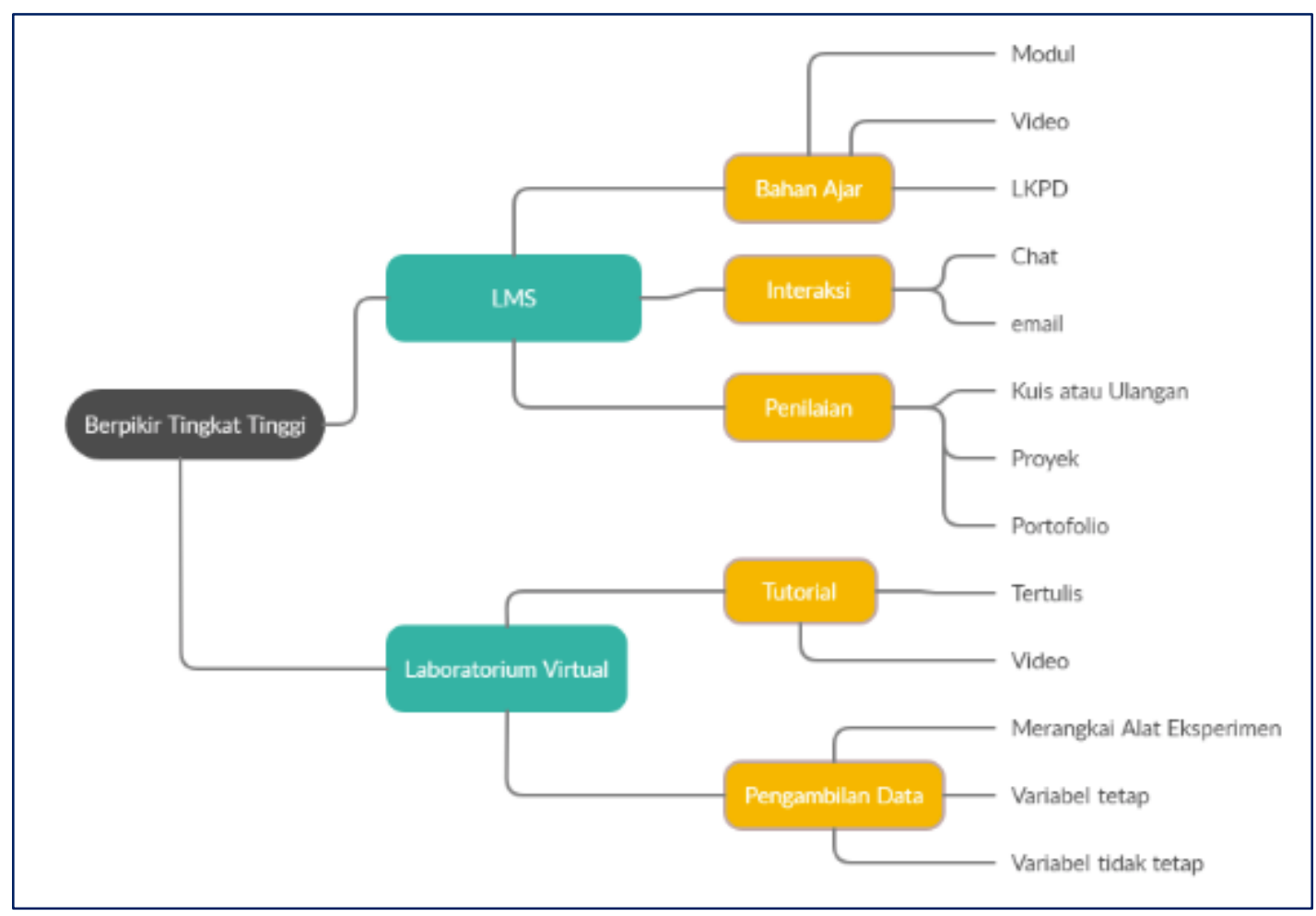

Gambar 2. Mind Mapping Pembelajaran Hukum Ohm

Dengan desain inovasi pembelajaran seperti di atas, diharapkan peserta didik mendapatkan hasil yang bagus melalui proses yang menyenangkan dan melatih peserta didik untuk selalu berpikir kritis.

Google Classroom merupakan aplikasi yang lengkap, karena memiliki banyak fasilitas pembelajaran di dalamnya. Pendidik bisa membuat kelas sendiri, lalu membagikan kode kelas tersebut ke peserta didik atau mengundang para peserta didik untuk bergabung dalam kelas. Menu yang digunakan dalam rancangan pembelajaran ini antara lain Gmeet, Forum, Tugas Kelas, Anggota, dan Nilai.

Gmeet digunakan sebagai sarana tatap maya melalui pertemuan tatap muka secara virtual. Pendidik melakukan penjelasan mengenai materi yang akan diajarkan, petunjuk pelaksanaan pembelajaran maupun diskusi pembelajaran Bersama seluruh peserta didik dalam kelas tersebut. Melalui Gmeet, pendidik melakukan tahap-tahap pembelajaran seperti pada Tabel 2.

\section{Tabel 2.Tahap-tahap Pembelajaran Hukum Ohm Menggunakan Laboratorium Virtual}

\section{Kegiatan Pendahuluan}

- Pendidik menyiapkan kelas untuk belajar, membagi kelompok dan membagikan materi dan LKPD

\section{Kegiatan Pembelajaran}

Stimullasi

- Peserta didik membaca LKPD dan membuka file laboratorium virtual tenang Hukum Ohm.

- Pendidik membibing peserta didik untuk membaca langkah kegiatan pengambilan data mendan laboratorium virtual.

Identifikasi - Peserta didik mengidentifikasi masalah yang berkaitan dengan Hukum Ohm.

Masalah

Pengumpulan - Peserta didik merangkai tegangan, hambatan, voltmeter, dan ammeter sesuai dengan

Data petunjuk pada LKPD.

Pembelajaran Berbasis Laboratorium Virtual Melalui Google Classroom pada Materi Hukum Ohm untuk Meningkatkan....

Marini Amalia Ocvianti, Dwi Sulisworo 
- Peserta didik mengambil data sesuai petunjuk pada LKPD.

Pengolahan

Data

Verifikasi

/pembuktian

Menarik

Kesimpulan

- Peserta didik mengolah data dengan membuat grafik hubungan antara arus dan tegangan.

- Peserta didik mengolah grafik dengan mencari kemiringan grafik.

- Peserta didik mencari nilai hambatan yang digunakan berdasarkan kemiringan grafik.

- Peserta didik mendiskusikan hasil hambatan yang diperoleh dari pengolahan data dan memverifikasi hasilnya dengan nilai hambatan yang digunakan pada laboratorium virtual.

- Peserta didik menyimpulkan tentang cara merangkai resistor, voltmeter dan ammeter.

- Peserta didik menyimpulkan tentang nilai hambatan hasil yang diperoleh dari hasil percobaan.

- Peserta didik menuliskan hasil diskusinya dengan melengkapi LKPD.

\section{Kegiatan Penutup}

- Pesarta didik mengunggah LKPD yang sudah dikerjakan pada LMS.

Menu Forum digunakan untuk mengirim pengumuman, memulai diskusi kelas, memposting hal-hal yang berkaitan dengan pembelajaran, dan memberikan respon atau komentar terhadap postingan tersebut. Menu Tugas Kelas digunakan untuk menempelkan tugas, tugas kuis, pertanyaan, dan materi. Pada kegiatan pembelajaran ini pendidik menempelkan LKPD, file laboratorium virtual, dan materi sebrelum pelaksanaan pembelajaran melalui Gmeet. Peserta didik bisa mengunduh semua yang dibagikan oleh pendidik. Ini dilakukan supaya peserta didik mempelajari materi lebih dahulu sebelum mulai pembelajaran.

Menu Anggota digunakan untuk menambah atau mengundang peserta didik untuk bergabung dalam kelas. Menu Nilai berfungi untuk memantau kemajuan setiap peserta didik dengan memberikan nilai pada tugas, dan memberi komentar dan mengeditnya.

Rancangan pembelajaran yang telah dibuat kemudian disusun dalam Google Classroom. Langkah pertama adalah memastikan semua peserta didik untuk login dan gabung ke kelas masingmasing pada Google Classroom. Untuk kelas yang diikuti akan muncul di halaman depan Google Classroom seperti pada gambar 3.

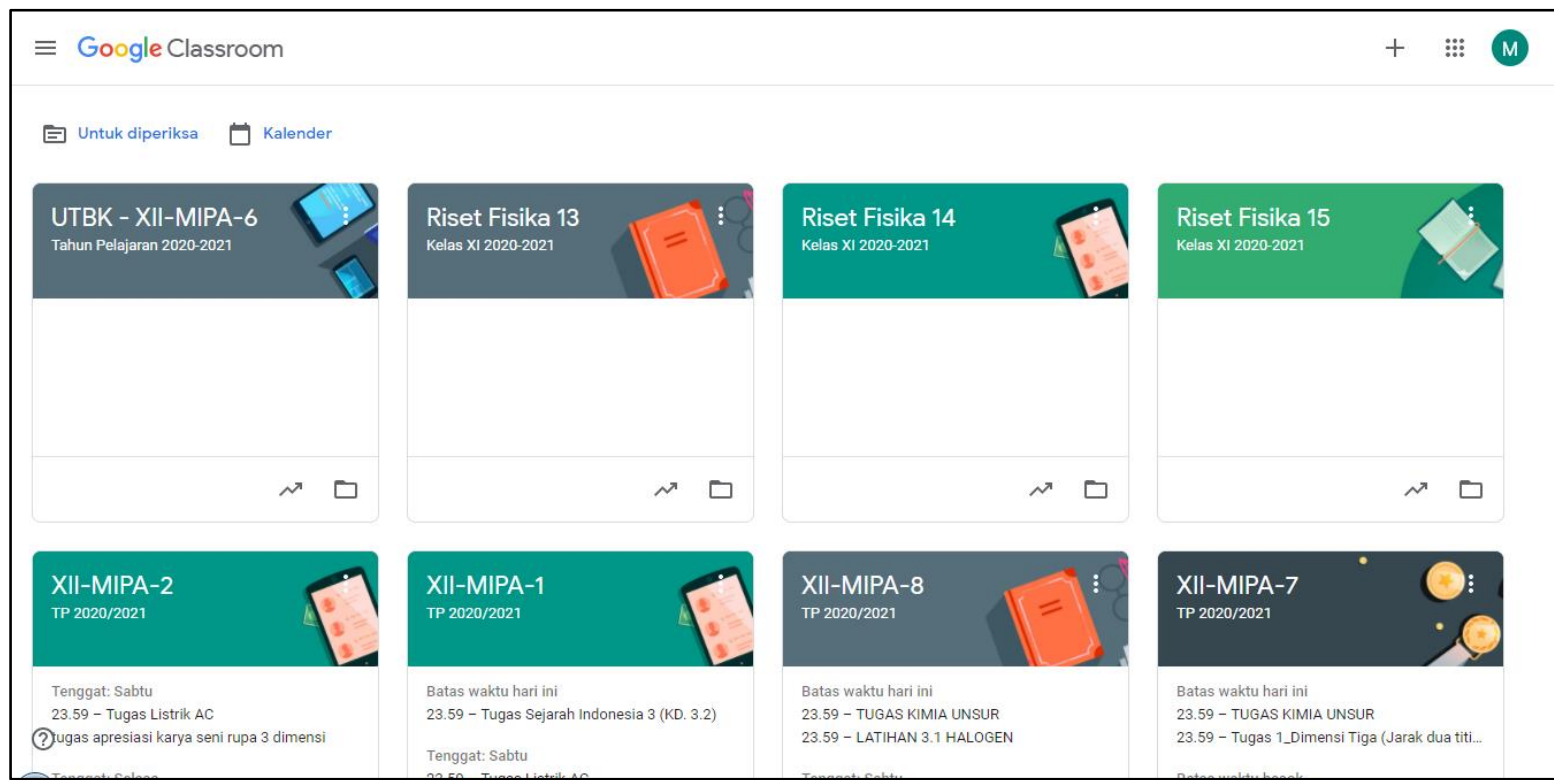

Gambar 3. Tampilan Halaman Depan Google Classroom 
Selanjutnya guru mengunggah materi pembelajaran (teks, video, link, presentasi ppt), tugas, ulangan, kuis, dan pertanyaan interaktif melalui menu Tugas Kelas seperti gambar 4.

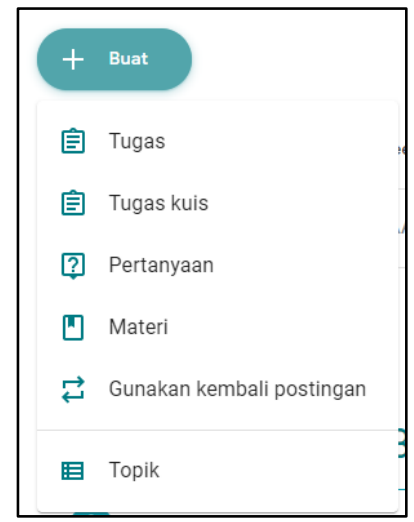

Gambar 4. Menu untuk Mengunggah Materi Pembelajaran

Tampilan materi dan tugas pada Google Classroom yang sudah diunggah akan tampak seperti gambar 5 dan gambar 6.

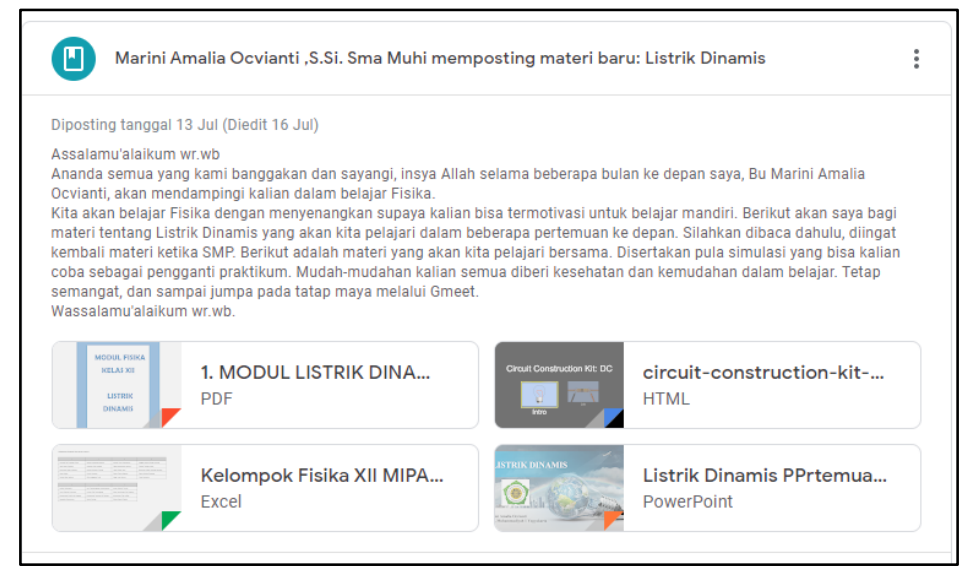

Gambar 5. Contoh Materi Pembelajaran yang Sudah Diunggah

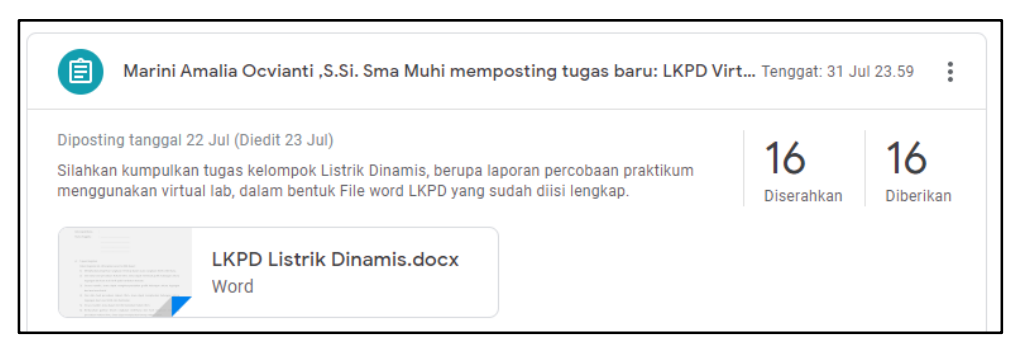

Gambar 6. Contoh Tugas yang Sudah Diunggah dan Dikerjakan oleh Peserta Didik

Menu Gmeet bisa dibuka pada link meeting yang sudah disediakan pada masing-masing kelas seperti gambar 7 .

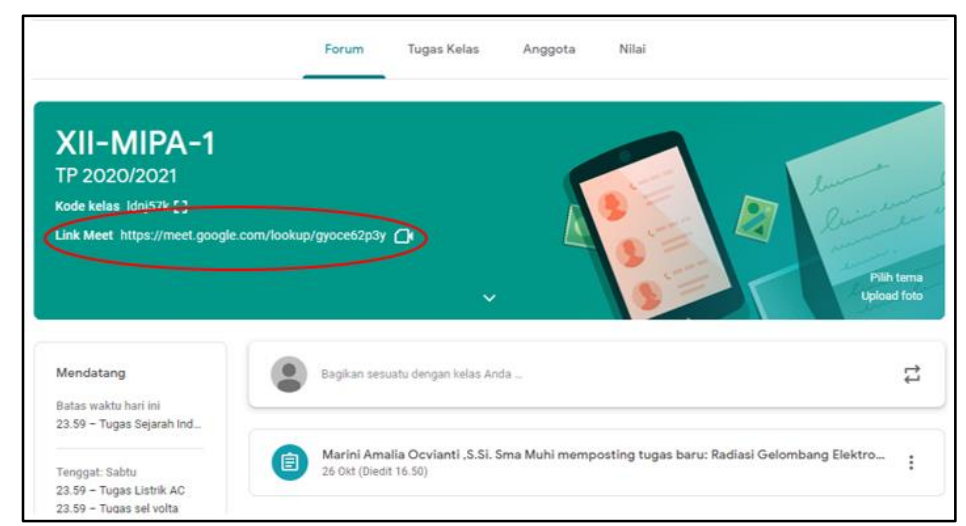

Gambar 7. Link Meeting yang Disediakan pada Masing-masing Kelas 
Selain bisa melakukan presentasi melalui Gmeet, interkasi antara guru dan peserta didik dilakukan melalui forum chat yang tersedia pada menu di pojok kanan atas. Proses tatap maya melalui Gmeet dilakukan untuk menjelaskan langkah-langkah pengambilan data pada laboratorium virtual dan cara pengisian LKPD yang telah disiapkan. Dalam proses ini akan muncul interaksi aktif yang akan merangsang kemampuan peserta didik untuk berpikir kritis. Proses tersebut bisa dilihat pada gambar 8 .

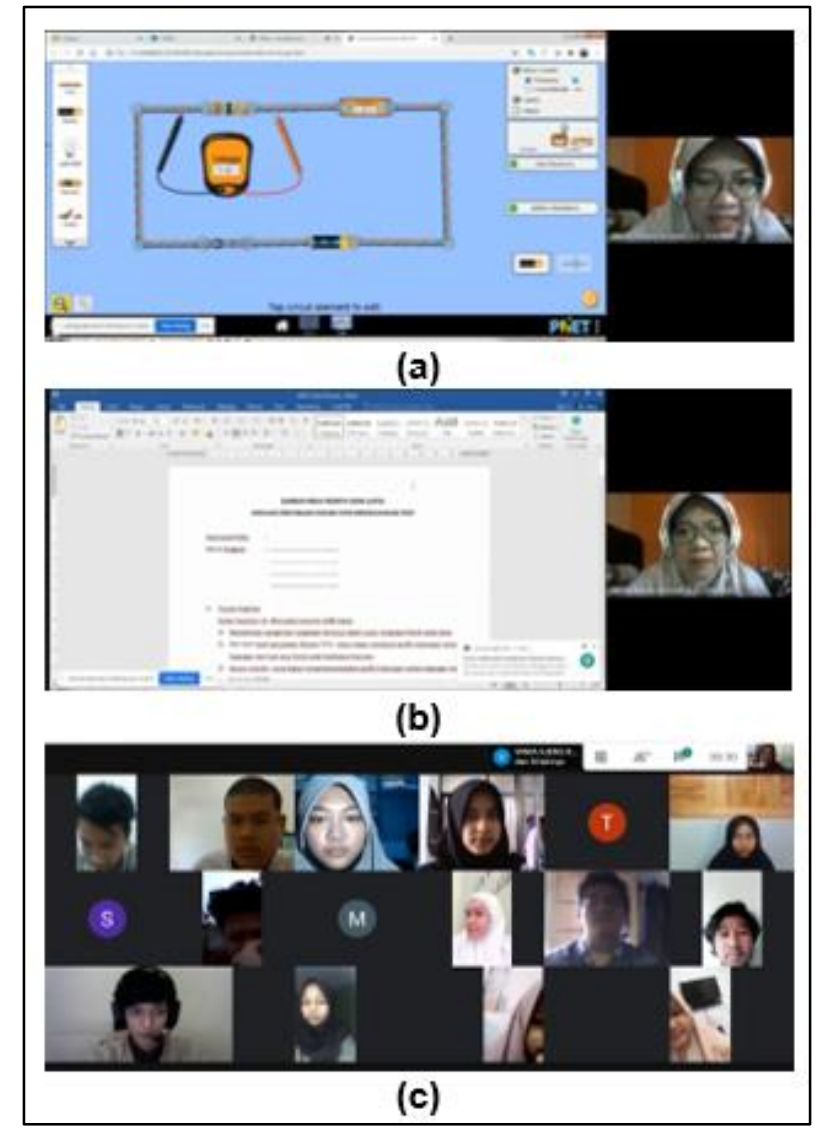

Gambar 8. (a) Penjelasan Penggunaan Laboratorium Virtual; (b) Penjelasan Cara Pengisian LKPD;

(c) Proses Diskusi yang Terjadi

\section{HASIL DAN PEMBAHASAN}

Setelah melaksanakan pembelajaran, pendidik menyebar angket kepada peserta didik untuk mengetahui respon mereka dalam pembelajaran menggunakan Google Classroom. Dari 40 responden yang mengisi angket, dapat dianalisa bahwa persentase responden yang menyetujui dan sangat menyetujui proses pembelajaran, penggunaan media, manfaat media, dan kefleksibelan proses pembelajaran menggunakan Google Classroom lumayan tinggi dengan persentase lebih dari 50\%. Data ini bisa dilihat dalam diagram pada gambar 9, gambar 10, dan gambar 11.

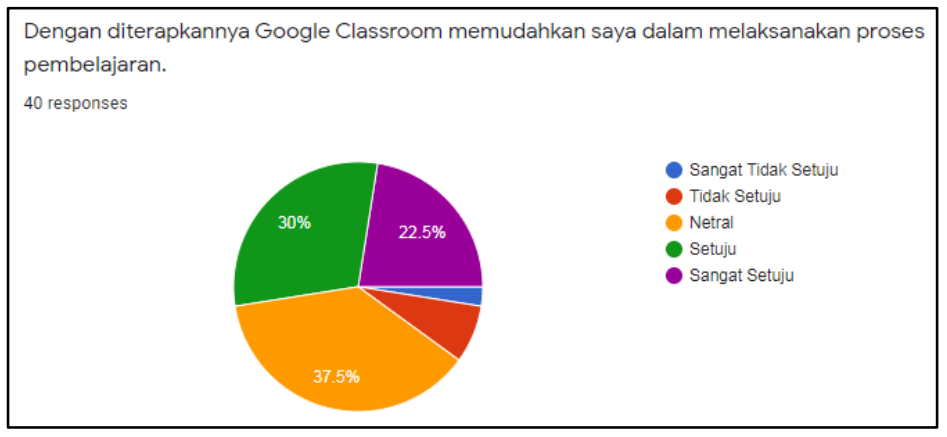

Gambar 9. Hasil Angket Responden 


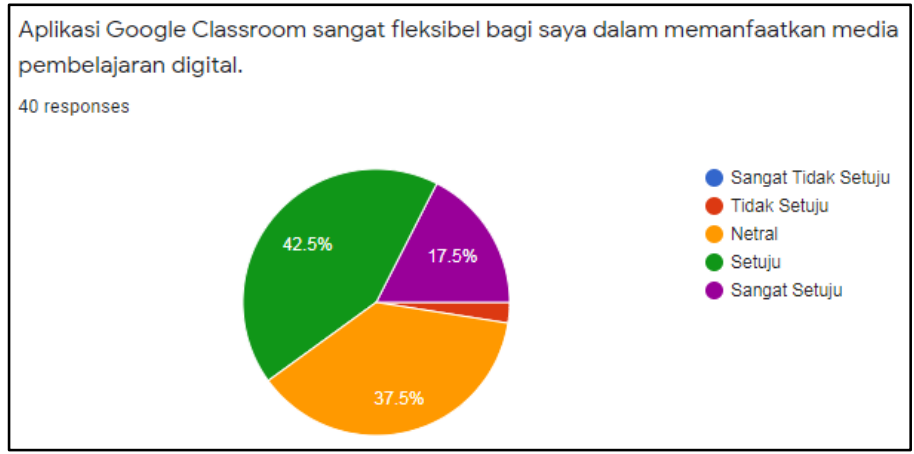

Gambar 10. Hasil Angket Responden

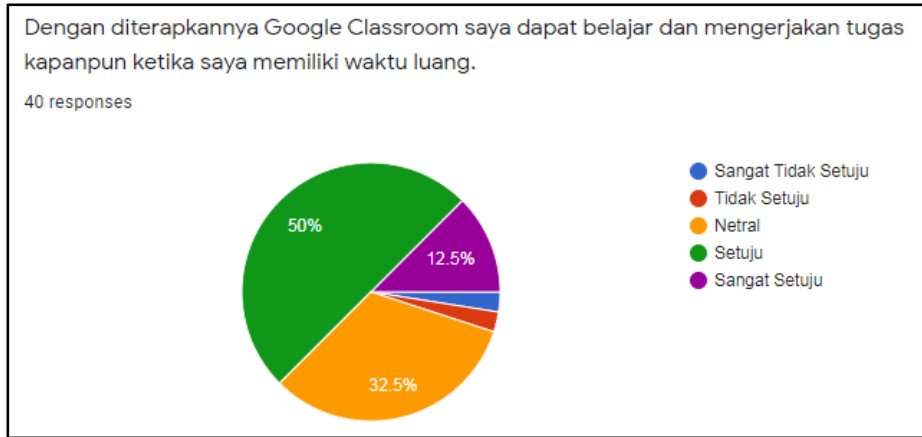

Gambar 11. Hasil Angket Responden

Sedangkan hasil lengkap dari angket bisa dilihat paga Tabel 3.

Tabel 3. Hasil Lengkap Angket Responden

\begin{tabular}{cccccc}
\hline No & STS & TS & N & S & SS \\
\hline 1 & 0 & 0 & 20 & 42.5 & 37.5 \\
2 & 2.5 & 7.5 & 37.5 & 30 & 22.5 \\
3 & 2.5 & 2.5 & 30 & 42.5 & 22.5 \\
4 & 2.5 & 2.5 & 32.5 & 50 & 12.5 \\
5 & 0 & 2.5 & 37.5 & 42.5 & 17.5 \\
6 & 0 & 0 & 50 & 32.5 & 17.5 \\
7 & 0 & 15 & 55 & 25 & 5 \\
8 & 0 & 0 & 80 & 10 & 10 \\
Rata-rata & $\mathbf{1}$ & $\mathbf{4}$ & $\mathbf{4 3}$ & $\mathbf{3 4}$ & $\mathbf{1 8}$ \\
*dalam \% & & & & & \\
\hline
\end{tabular}

Dari hasil pada Tabel 3 dapat diketahui bahwa respons positif berupa setuju dan sangat setuju mengenai penggunaan Google Classroom dalam pembelajaran adalah sebesar 52\%, netral 43\%, dan respon setuju dan sangat tidak setuju sebesar 5\%. Hasil ini bisa membuktikan bahwa pembelajaran menggunakan Google Classroom bermanfaat dan efektif dalam pembelajaran, khususnya dalam membantu cara peserta didik untuk dapat berpikir kritis, melalui inovasi pembelajaran dengan laboratorium virtual.

Penelitian yang dilakukan oleh Hapsari menggunakan paradigma interpretif, dengan pendekatan kualitatif dan metode studi kasus untuk menemukan pemanfaatan Google Classroom oleh dosen Universitas Dian Nuswantoro khususnya di departemen Ilmu Komunikasi, pada kelas Pengolahan Konten Digital. Peran media baru di sektor pendidikan ini menghasilkan proses yang begitu mudah untuk dilakukan dan menunjukan bahwa hasil penyelesaiannya membutuhkan program pembelajaran campuran atau blended Learning dalam berkomunikasi yang baik di era digital (8). 
Berdasar penelitian Zurimi, penggunaan e-learning berbasis google classroom memberikan banyak kemudahan kepada peserta didik, diantaranya Google Classroom dapat diakses dimana saja dan kapan saja, penerapan Google Classroom ini juga dapat digunakan melalui smartphone berbasis android. Berdasarkan hasil penelitian disimpulkan bahwa penggunaan e-learning berbasis Google Classroomsangat bermanfaat sebagai media pendukung dalam inovasi pembelajaran. Karena dengan adanya media e-learning berbasis Google Classroom peserta didik dapat mempelajari materi secara lebih intensif dan mandiri, selain mudah untuk digunakan e-learning berbasis Google Classroom juga memberikan wadah diskusi (10).

Harefa dan Sumiyati dalam penelitiannya menyimpulkan bahwa ecara umum, peserta didik memiliki persepsi yang baik terhadap pengimplementasian Google Classroompada pembelajaran selama masa pandemi Covid-19. Kendati demikian, peserta didik mengindikasikan bahwa sistem pembelajaran konvensional (tatap muka) masih sangat dibutuhkan melalui interpretasi data dari beberapa indikator penelitian (7).

Dari ketiga hasil penelitian sebelumnya bisa dikatakan bahwa penggunaan LMS yaitu Google Classroom dalam pembelajaran dinilai efektif dalam pembelajaran. Tetapi peserta didik tetap membutuhkan proses pembelajaran secara langsung atau tatap muka. Sehingga diperlukan kombinasi proses pembelajaran antara tatap muka dan tatap maya, yang dikenal dengan istilah blended learning (12). Penggunaan blended learning dalam proses pembelajaran menggunakan media pembelajaran yang memanfaatkan teknologi. Sedangkan cara dan gaya mengajar dilakukan secara terbuka, dan saling berinteraksi baik melalui tatap muka maupun tatap maya. Belajar dari pengalaman pelaksanaan pembelajaran selama masa pandemi Covid-19, dimana penggunaan teknologi informasi menjadi sebuah keharusan dalam proses pembelajaran, maka blended learning akan menjadi model baru dalam pembelajaran (10).

\section{SIMPULANDANSARAN}

\subsection{Simpulan}

LMS merupakan sebuah aplikasi yang digunakan dalam proses pembelajaran daring. Salah satu LMS yang sering digunakan adalah Google Classroom. Pendidik bisa merencanakan, mengimplementasi, dan memberikan penilaian pembelajaran kepada peseta didik secara daring. Penggunaan Google Classroom dirasa lebih mudah karena fitur menu yang sederhana dan mudah dipahami. Selain itu Google Classroom mempunyai menu yang lengkap untuk membantu proses pembelajan. Pendidik bisa memberikan materi dalam bentuk teks, gambar, animasi, bahkan video. Pendidik juga bisa memberikan penugasan biasa maupun berbentuk kuis. Tugas yang dusah dinilia bisa dilihat oleh peserta didik. Interaksi pendidik dan peserta didik melalui Google Classroom dilaksanakan dengan diskusi melalui forum diskusi maupun dengan tatap maya secara langsung pada menu Gmeet, sehingga pembelajaran akan lebih efektif.

Pembelajaran menggunakan laboratorium virtual pada materi Hukum Ohm yang dilakukan melalui Google Classroom ini membantu peserta didik untuk melatih keterampilan berpikir kritis, yaitu melalui proses perencanaan pengambilan, pengambilan, dan pengolahan data yang dilakukan secara diskusi dalam kelompoknya.

\subsection{Saran}

Melalui angket yang telah diisi oleh peserta didik, sebagian besar peserta didik menyetujui proses pembelajaran, penggunaan media, manfaat media, dan kefleksibelan proses pembelajaran menggunakan Google Classroom. Sehingga untuk selanjutnya penggunaan Google Classroom dalam pembelajaran bisa tetap dilaksanakan dikombinasikan dengan pembelajaran secara tatap muka.

\section{DAFTARPUSTAKA}

1. Oduntan O. The International Journal Of Science \& Technoledge Learning Management System: A Tool for Effective Teaching Process. 2018 Sep 25;

2. Kasim NNM, Khalid F. Choosing the right learning management system (LMS) for the 
higher education institution context: A systematic review. Int J Emerg Technol Learn. 2016;11(6):55-61.

3. Saputro B, Susilowati AT. Effectiveness of Learning Management System (LMS) on InNetwork Learning System (SPADA) based on scientific. J Educ Gift Young Sci. 2019;7(3):481-98.

4. Wibowo AT, Akhlis I, Nugroho SE. Pengembangan LMS (Learning Management System) Berbasis Web untuk Mengukur Pemahaman Konsep dan Karakter Siswa. Sci J Informatics. 2015;1(2):127-37.

5. Turino, Purwanto Y, Soeleman A. E-learning bahasa Inggris Berbasis Web. 2009 Oct;5(2):726-39.

6. Jaya H. Pengembangan laboratorium virtual untuk kegiatan paraktikum dan memfasilitasi pendidikan karakter di SMK. J Pendidik Vokasi. 2013 Jan;2(1).

7. Harefa N, Sumiyati S. Persepsi Siswa terhadap Google Classroom sebagai LMS pada masa Pandemi Covid-19. Sci Educ Appl J. 2020;2(2):88.

8. Hapsari SA, Pamungkas H. Pemanfaatan Google Classroom Sebagai Media Pembelajaran Online di Universitas Dian Nuswantoro. WACANA J Ilm Ilmu Komun. 2019 Dec;18(2):225-33.

9. Nurfalah E. Optimalisasi E-Learning berbasis Virtual Class dengan Google Classroom sebagai Media Pembelajaran Fisika. Phys Educ Res J. 2019 Aug;1(1):46.

10. Zurimi S. Penggunaan E-Learning Berbasis Google Classroom Sebagai Media Pendukung Dalam Pembelajaran Matematika di MTS Negeri Tulehu. JTRISTE. 2019;6(1):1-8.

11. Tumengkol AA. Pengalaman Pembelajaran Berbasis Blended Learning Mata Kuliah Ilmu Alamiah Dasar Menggunakan Google Classroom Pada Mahasiswa Geografi. J Episentrum. 2020 Apr;1(1):39.

12. Loendorf WR. Using a Blended Learning Format to Extend the Influence of a Technological Literacy Course Using a Blended Learning Format to Extend the Influence of a Technological Literacy Course. 2015. 